\title{
RESPONSE SURFACE METHODOLOGY AND DESIRABILITY FUNCTION AS STATISTICAL TOOLS IN THE OPTIMIZATION OF ELECTROCOAGULATION PROCESS IN SURFACE WATER
}

\section{METODOLOGIA DE SUPERFÍCIE DE RESPOSTA E FUNÇÃO DE DESEJABILIDADE COMO FERRAMENTAS ESTATÍSTICAS NA OTIMIZAÇÃO DO PROCESSO DE ELETROCOAGULAÇÃO EM ÁGUA DE SUPERFÍCIE}

\author{
M. P. M. COMBATT ${ }^{a}$, E. L. REIS ${ }^{\mathrm{b},}$, K. E. V. SANJUAN ${ }^{\mathrm{c}}$, A. A. NEVES ${ }^{\mathrm{b}}$ and R. C. S. MENDONÇA ${ }^{\mathrm{a}}$ \\ ${ }^{\text {a }}$ Department of Food Technology, Federal University of Viçosa, Viçosa, Minas Gerais, Brazil \\ ${ }^{\mathrm{b}}$ Department of Chemistry, Federal University of Viçosa, Viçosa, Minas Gerais, Brazil \\ ${ }^{\mathrm{c}}$ Department of Civil Engineering, Federal University of Viçosa, Viçosa, Minas Gerais, Brazil
}

* Corresponding author: Federal University of Viçosa, Department of Chemistry, Viçosa, Minas Gerais, Brasil, Phone +55 3138913959

e-mail address: efraimreis@gmail.com (E. L. Reis)

\section{A R T I C LE IN F O}

\section{Article history:}

Received 2020-04-09

Accepted 2020-06-17

Available online 2020-06-17

keywords

Coagulation

Central composite design

Electrolysis

Water treatment
A B S T R A C T

Electrocoagulation in waters clarification was studied as an alternative in water treatment processes. The objective was to optimize the process for water samples in different turbidity conditions, considering the current intensity, electrolysis time and initial $\mathrm{pH}$ in the apparent color removal, chemical oxygen demand and turbidity. Electrocoagulation tests were made with aluminum electrodes. The optimal operating conditions and models based on the response surface methodology were obtained with central composite design. To meet the esthetic / organoleptic standard stipulated for this stage of the process, the desired characteristics of three examined water samples were: color $<15 \mathrm{uH}, \mathrm{COD}<18 \mathrm{mg} \mathrm{L}^{-1} \mathrm{O}_{2}$ and turbidity $<5$ NTU. Correlating the analyzed responses, specific conditions were found for the parameters in determining safe work points in the clarification operation.

\section{palavras-chave}

Coagulação

Planejamento composto central

Eletrólise

Tratamento de água

\begin{abstract}
R E S UM O
A eletrocoagulação na clarificação de água foi estudada como uma alternativa no processo de tratamento de águas. O objetivo foi otimizar o processo para amostras de água em diferentes condições de turbidez, considerando a intensidade de corrente, tempo de eletrólise e pH inicial na remoção aparente de cor, demanda química de oxigênio e turbidez. Os testes de eletrocoagulação foram realizados com eletrodos de alumínio. As condições operacionais ideais e os modelos baseados na metodologia da superficie de resposta foram obtidos com um planejamento composto central. Para atender ao padrão estético / organoléptico estipulado para esta etapa do processo, as características desejadas das três amostras de água examinadas foram: cor $<15 \mathrm{uH}, \quad \mathrm{DQO}<18 \mathrm{mg} \mathrm{L}^{-1} \mathrm{O}_{2} \quad e$ turbidez $<5$ NTU). Correlacionando as respostas, encontraram-se condições específicas para os parâmetros seguros para a clarificação.
\end{abstract}




\section{INTRODUCTION}

Access to drinking water has been a problem well addressed by government policies as shown by UNICEF and the World Health Organization in the report "Progress on sanitation and drinking water: 2015 update and MDG assessment." This report highlights the path ahead, especially in rural areas where access to improved sources of drinking water is difficult; 663 million people did not have access to this basic good by 2015; eight out of 10 lived in rural areas (UNICEF and WHO, 2019). Transportation and stock of chemicals used in conventional water treatment can also be an issue in rural areas, where there are not adequate means of transport to reach the farthest places.

Electrocoagulation (EC) is an alternative clarification treatment that presents comparative advantages related to process automation Holt et al., 2005; Valente et al., 2014; Moussa et al., 2017). Among the advantages that the technology offers, it can be used conveniently in rural areas where electricity is not available, as long as a photovoltaic system is coupled to the unit. In addition, frequent shipping of chemicals, their stock or handling is not necessary. The electrocoagulation process needs an electrolytic reactor with sacrificial electrodes that release coagulant chemical species. The application of an electric potential causes corrosion in the anode by oxidation, followed by cation solvation and, consequently, formation of the hydrolyzed species. At the same time, the applied potential forms hydrogen microbubbles at the cathode of the reactor by reduction reactions (Chen, 2004).

Electrocoagulation has been used to treat surface and groundwater, aiming to find the best parameters for pollutant removal such as arsenic (Jadhav et al., 2015; Kobya et al., 2015), heavy metals (Escobar et al., 2006; Mouedhen et al., 2008) and others (Moussa et al., 2017; Ghernaout et al., 2013; Zhu et al., 2005). The latest research in the area focuses on organic matter removal, using humic acid removal as reference to evaluate the efficiency of electrolytic process as a treatment for drinking water, since during water chlorination, humic substances cause the formation of disinfection byproducts precursors of carcinogenic compounds (Dubrawski et al., 2013; Ulu et al., 2014). Although humic acid analyses are important, there are other routine parameters measured in conventional water treatment systems (WTSs) to evaluate process efficiency. Turbidity and color are easy to measure.
They are economical and are within the aesthetic/organoleptic parameters suggested for measurement by most drinking water guidelines (Pinto et al., 2012).

The aim of any treatment is to ensure that all these water pollutants are within the potability standard. However, finding the desirable operating conditions between the input variables to meet the required concentrations for various pollutants requires statistical methodologies that handle several parameters simultaneously. The desirability function optimizes multiple responses at the same time Vojnovic et al., 1993). This function suggests the values of the independent parameters that provide the desirable response for the product or process (Islam et al., 2009; Kobya et al., 2013).

Electrolysis time, current intensity and initial $\mathrm{pH}$ of the medium are proportional to the coagulant concentration in the medium and in the $\mathrm{pH}$ of the solution in the electrocoagulation process. These last two parameters control the coagulation processes. They influence the type of species in the medium and consequently the coagulation mechanism being favored (Amirtharajah et al., 1982; Duan et al., 2003).

Color and turbidity are common indicators of operational control of the WTSs. Natural water bodies have different characteristics depending on the rainfall and drought regimes, and the proposed treatment must meet the clarification issue without changing the natural conditions of the surface body. Therefore, in order to improve the coagulation process in water treatment and to guarantee water production according to the potability standard, treatability tests should occur as often as possible (Bastos et al. 2020). Evidently, clarification treatments should have operational flexibility in the face of changes in the climatic conditions of surface water bodies.

To describe the effects and relationships of the various variables in the electrocoagulation process, a mathematical model should be used. Thus, the response surface methodology (RSM), which is a collection of mathematical and statistical techniques, was used to improve the relative significance of variables that affect the coagulation process during treatment. The three-dimensional graphical perspective of the model is called the response surface, the surface analysis can also use contour graphics for its interpretation. 
MSR has been widely used to study and optimize the parameters that affect the efficiency of the electrocoagulation process. The MSR and the desirability function were used successfully in other research in the area, such as in the optimization of the electrocoagulation process to remove arsenic in drinking water (Kobya et al., 2013), organic material from poultry slaughterhouse effluents (Mendoza et al., 2017) and different pollutants when using the electrocoagulation - electroflotation set (Jimenéz et al., 2016).

The objectives of this study were: to model and optimize water electrocoagulation process with different characteristics of initial turbidity, considering the effect of current intensity, electrolysis time and initial $\mathrm{pH}$ on the removal of apparent color, chemical oxygen demand (COD) and turbidity of natural waters. To find safe operating parameters in the electrocoagulation process that lead to desirable values of apparent color removal, COD and turbidity simultaneously.

\section{MATERIAL AND METHODS}

\subsection{Electrocoagulation tests}

The tests occurred in a batch with the Jar test apparatus (Milan brand, model JT102/6).

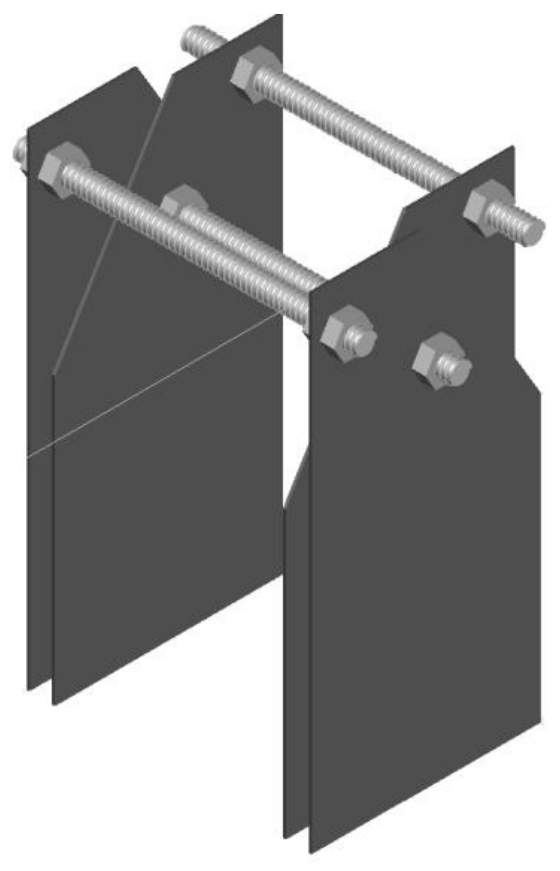

Figure 1. Electrode design proposed for electrocoagulation.

The electrodes, as shown in figure 1, were constructed using four $99 \%$ aluminum plates with dimensions of $80 \times 170 \times 1.2 \mathrm{~mm}$ (width, length and thickness respectively), a contact surface area of $0.064 \mathrm{~m}^{2}$, maintaining a relation between the area of the electrode and the volume of effluent of 42 $\mathrm{m}^{2} \mathrm{~m}^{-3}$ in each test (Figure 1). The distance between the electrode plates was adjusted by $10 \mathrm{~mm}$ thick teflon spacers. The direct current was applied by a single-pole parallel type electrical connection using a controlled current supply (Skilltec brand, model Skfa-05d).

Electrocoagulation (EC), flocculation and sedimentation processes were developed to simulate clarification in the complete cycle treatment by replacing conventional coagulation by EC. In the EC, we used a fast mixing rate of $100 \mathrm{rpm}$ (rapid mixing gradient $90 \mathrm{~s}^{-1}$ ). The flocculation and sedimentation experiments were conducted according to the hydraulic parameters described in the local standard for stations with a capacity of up to $1000 \mathrm{~m}^{3} \mathrm{~d}^{-1}$ (ABNT, 2019).

\subsection{Collection and characterization}

The water types were collected from São Bartolomeu river (Viçosa; MG, Brazil) and in a dam in different climatic periods following the procedure proposed by Di Bernado et al. (2002) based on the operational records of Water Treatment System (WTS) in the Universidade Federal de Viçosa (UFV) from 2014 to 2016. Figure 2 shows the variation of raw water turbidity observed in that period.

Table 1. Turbidity values found in raw water samples on selected dates in the collection periods.

\section{Turbidity (NTU) Date of sample collection}

\begin{tabular}{cc}
\hline Low $(<10)$ & $26 / 07 / 2017$ \\
\hline Medium $(11-50)$ & $28 / 02 / 2018$ \\
\hline High $(>50)$ & $08 / 03 / 2018$ \\
\hline
\end{tabular}

Table 1 shows the periods of collection of the determined raw water samples once studied and analyzed the history of turbidity parameters of the last three years of the water treatment plant.

Water samples with low, medium and high initial turbidity were stored for up to two weeks and characterized according to the standard methods (APHA, 2016). 


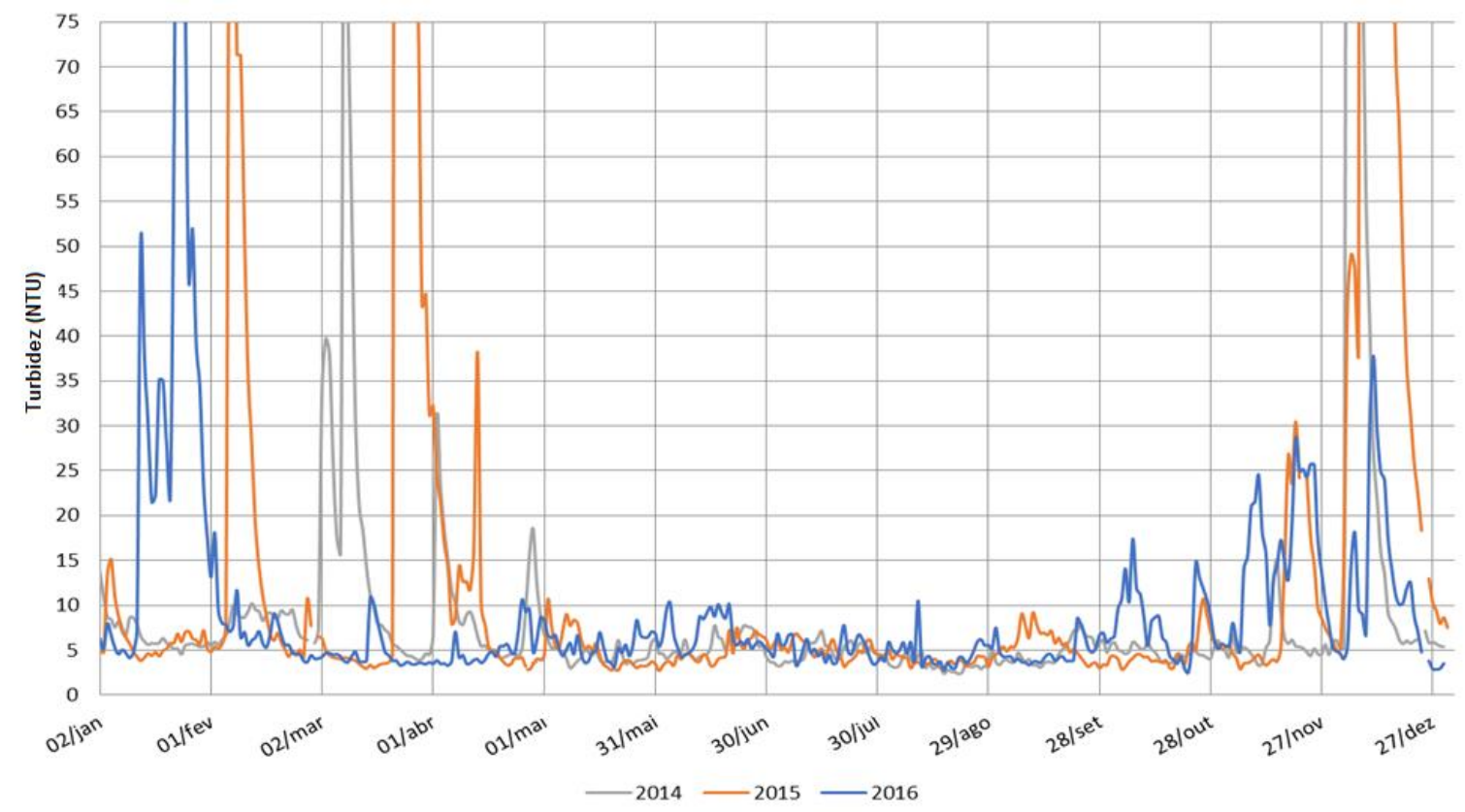

Figure 2. Turbidity values observed over three years. Operational data of WTS-UFV.

All characterization analyzes were performed turbidity of each type of water to reach the standard in triplicate, according Table 2. Table 3 shows the established in this study. required percent values of color removal, COD and

Table 2. Characterization averages of the three types of raw water.

\begin{tabular}{cccc}
\hline Parameter & $\begin{array}{c}\text { Low } \\
\text { turbidity }\end{array}$ & $\begin{array}{c}\text { Medium } \\
\text { turbidity }\end{array}$ & $\begin{array}{c}\text { High } \\
\text { turbidity }\end{array}$ \\
\hline Turbidity $(\mathrm{NTU})$ & $5.00 \pm 0.36$ & $18.00 \pm 3.06$ & $464.0 \pm 4.0$ \\
\hline Apparent color $(\mathrm{uH})$ & $20.0 \pm 2.6$ & $31.0 \pm 2.3$ & $331.0 \pm 26.0$ \\
\hline Total COD $\left(\mathrm{mg} \mathrm{L}^{-1} \mathrm{O}_{2}\right)$ & $23.00 \pm 3.39$ & $18.00 \pm 1.21$ & $47.00 \pm 2.53$ \\
\hline $\mathrm{pH}$ & $7.53 \pm 0.07$ & $7.24 \pm 0.14$ & $6.88 \pm 0.07$ \\
\hline Conductivity $\left(\varepsilon \mathrm{S} \mathrm{cm}^{-1}\right)$ & $67.20 \pm 4.76$ & $74.00 \pm 0.48$ & $75.90 \pm 4.42$ \\
\hline Acidity $\left(\mathrm{mg} \mathrm{L}^{-1} \mathrm{CaCO}_{3}\right)$ & $4.09 \pm 0.05$ & $1.05 \pm 1.03$ & $1.03 \pm 0.01$ \\
\hline Alkalinity $\left(\mathrm{mg} \mathrm{L}^{-1} \mathrm{CaCO}_{3}\right)$ & $28,7 \pm 0.5$ & $27.6 \pm 0.3$ & $28.50 \pm 1.75$ \\
\hline Phosphorus $\left(\mathrm{mg} \mathrm{L}^{-1}\right)$ & $0.09 \pm 0.01$ & $0.08 \pm 0.02$ & $0.08 \pm 0.05$ \\
\hline
\end{tabular}

Table 3. Percent removal required to meet the established standard.

\begin{tabular}{cccc}
\hline Parameter & $\begin{array}{c}\text { Low } \\
\text { turbidity } \\
\text { water }\end{array}$ & $\begin{array}{c}\text { Medium } \\
\text { turbidity } \\
\text { water }\end{array}$ & $\begin{array}{c}\text { High } \\
\text { turbidity } \\
\text { water }\end{array}$ \\
\hline Turbidity removal & 0 & 72 & 98 \\
\hline Apparent color removal & 25 & 52 & 95 \\
\hline COD removal & 22 & 17 & 68 \\
\hline
\end{tabular}




\subsection{Experimental design, modeling} optimization of electrocoagulation process

The response surface methodology (RSM) was used to determine the proposed models and to define the best operating points in electrocoagulation. A rotational central compound design (RCCD) installed under the completely randomized design was used, and treatments were planned with three factors of combined interest: 4 to 9 initial $\mathrm{pH}$ (low and medium turbidity water) and 2.3 to 10.7 (high turbidity water), current intensity (0.03 $\ddot{i} 0.13 \mathrm{~A})$ and electrolysis time (10 ï $110 \mathrm{~s}$ ). Factor levels were chosen in agreement to the dose and $\mathrm{pH}$ data provided by WTS-UFV at the collection dates. Three replicates occurred at the central point to estimate the experimental error, with 17 trials. The values used to evaluate the efficiency of the electrocoagulation process were parameters established by international guidelines and should be less than $15 \mathrm{uH}$ for color and $5 \mathrm{NTU}$ for turbidity to comply with the aesthetic/organoleptic standard (Pinto et al., 2012).

Similarly, the COD indicator was $18 \mathrm{mg} \mathrm{L}^{-1}$ $\mathrm{O}_{2}$ following the safety standards used in the WTS-UFV for this process stage. Two models are sent for each evaluated response according to the type of studied water: the coded model allows analyzing the importance that each term of the equation has on the response by comparing the coefficients magnitude. The uncoded model allows obtaining the actual values of removal once the values of the studied parameters are replaced. The coefficient of determination and the lack of fit for each model are presented, as well as the best operating point considering the study range of the three input parameters.

The desirability function was used to simultaneously optimize the multiple responses under study. The adopted procedure involved two steps. First, the search for desirability when the lower limit of permissible percentage removal is zero. The second stage considers the local standard as the permissible lower limit. Desirability function transforms each estimated response, calculated by fitting the ANOVA-associated model to a desirable value using the equations described by Vojnovic et al. (1993).

The Minitab (Minitab, 2004) software was used to develop the statistical models and the desirability function. Analysis of variance was performed for the response variables in which $\mathrm{p}$ - values indicate the significant terms of the model, at a 5\% level of significance. The verification of statistical analysis compliance to obtain the models took place using graphical tools to verify the assumptions of this analysis, by evaluating the normal distribution, homogeneity of variances and residue independence.

\section{RESULTS AND DISCUSSION}

3.1. Modeling and optimization of the
electrocoagulation process

Mathematical tools and optimization statistics were used to find safe work points in the electrolytic treatment operation for the sample. RSM and desirability function were used successfully in other studies, such as the optimization of the electrocoagulation process to remove arsenic for drinking water (Kobya et al., 2013), organic matter of poultry slaughterhouse effluent (Mendonza et al., 2017), and different pollutants when used electrocoagulation-electroflotation (Jimenéz et al., 2016).

Tables 4, 5 and 6 show the models obtained for percentage removal efficiency of color, COD and turbidity, respectively for significant variables considering a 95\% confidence interval ( $p<0.05)$. In the models, $\mathrm{C}$ is the percentage removal of apparent color $(\mathrm{uH}), \mathrm{COD}$ is the percentage removal of COD $\left(\mathrm{mg} \mathrm{L}^{-1} \mathrm{O}_{2}\right.$ ), $\mathrm{T}$ is the percentage removal of turbidity (NTU), $t$ is the electrolysis time (s), $\mathrm{pH}$ is the initial $\mathrm{pH}$ and $\mathrm{i}$ is the current electric intensity (A). For the found models, the values for coefficient of determination were good $\left(\mathrm{R}^{2}>0.7\right)$. Regarding the lack of fit, it was not significant (value $p>0.05$ ) for most of the equations. This result allows us to consider that an adequate adjustment has been reached, since the estimate of the residual mean square has not defects caused by the incorrect specification of the models. The graphs for the statistical conformity assessment were satisfactory.

\subsection{Color Removal}

The percentage removal of the color for water with low turbidity increases $(\mathrm{p}<0.05)$ due to the linear increase and decrease in $t$ and $\mathrm{pH}$ respectively, as well as the increase of $\mathrm{i}$ to $0.078 \mathrm{~A}$, increases $(p<0.05)$ with the linear growing of $t$ and $\mathrm{i}$, and the decrease of $\mathrm{pH}$. As the percentage of color removal for water with high turbidity, it increases ( $p$ $<0.05$ ) it provides a maximum removal. For water with medium turbidity, the color removal to the 
linear increase and decrease of $\mathrm{i}$ and $\mathrm{pH}$, respectively, as well as of the increase of t up to 90 $\mathrm{s}$, when the maximum removal occurs.

The negative sign of the iterations $\mathrm{t} x \mathrm{pH}$ and $\mathrm{i} \mathrm{x} \mathrm{pH}$ denotes antagonism between these parameters, so it is recommended that these two variables take opposite directions once the response is sought as shown in figure 3 . The estimated models indicated none possibility of achieving maximization of color removal for the three types of water, which means that the color removal could still be greater if the non-optimized parameters were displaced as shown in table 4.

Table 4. Coded and uncoded statistical models for percentage color removal of the samples.

\begin{tabular}{|c|c|c|c|c|}
\hline Sample & & Regression equation & $\mathbf{R}^{2}$ & $\mathbf{L F}$ \\
\hline \multirow{3}{*}{$\begin{array}{l}\text { Low water } \\
\text { turbidity }\end{array}$} & Cod & $\mathrm{C}=8.60+10.10 * \mathrm{t}+4.48 * \mathrm{i}-18.90 * \mathrm{pH}-16.39 * \mathrm{i}^{2}$ & \multirow{3}{*}{0.79} & \multirow{3}{*}{0.454} \\
\hline & Uncod & $\mathrm{C}=-90.7+0.337 * \mathrm{t}+4113 * \mathrm{i}-12.60 * \mathrm{pH}-26224 * \mathrm{i}^{2}$ & & \\
\hline & $\mathrm{BP}$ & $\mathrm{t}=110 ; \mathrm{i}=0.078 ; \mathrm{pH}=4$ & & \\
\hline \multirow{3}{*}{$\begin{array}{l}\text { Medium water } \\
\text { turbidity }\end{array}$} & Cod & $\mathrm{C}=54.34+11.52 * \mathrm{t}+14.1 * \mathrm{i}-18.45 * \mathrm{pH}$ & \multirow{3}{*}{0.73} & \multirow{3}{*}{0.023} \\
\hline & Uncod & $\mathrm{C}=68.9+0.384 * \mathrm{t}+565 * \mathrm{i}-12.30 * \mathrm{pH}$ & & \\
\hline & $\mathrm{BP}$ & $\mathrm{t}=110 ; \mathrm{i}=0.13 ; \mathrm{pH}=4$ & & \\
\hline \multirow{3}{*}{$\begin{array}{l}\text { High water } \\
\text { turbidity }\end{array}$} & Cod & $\mathrm{C}=58.41+2.85 * \mathrm{t}+5.46 * \mathrm{i}-21.08 * \mathrm{pH}-5.39 * \mathrm{t}^{2}-5.65 * \mathrm{t} * \mathrm{pH}-4.99 * \mathrm{i} * \mathrm{pH}$ & \multirow{3}{*}{0.96} & \multirow{3}{*}{0.237} \\
\hline & Uncod & $\mathrm{C}=1.3+1303 * \mathrm{t}+738 * \mathrm{i}+2.08 * \mathrm{pH}-0.00599 * \mathrm{t}^{2}-0.0753 * \mathrm{t} * \mathrm{pH}-79.9 * \mathrm{i} * \mathrm{pH}$ & & \\
\hline & $\mathrm{BP}$ & $\mathrm{t}=90 ; \mathrm{i}=0.1 ; \mathrm{pH}=3.3$ & & \\
\hline
\end{tabular}

Cod: model with coded coefficients; Uncod: model with uncoded coefficients; BP: best point; $\mathrm{R}^{2}$ : coefficient of determination; $\mathrm{LF}$ : lack of fit.

(a)

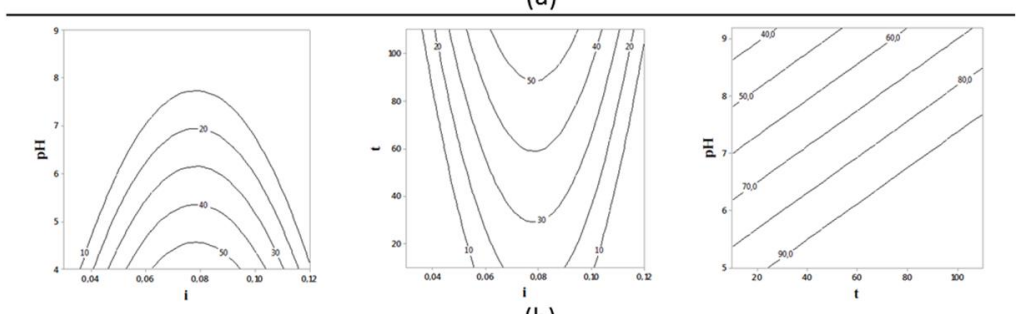

(b)

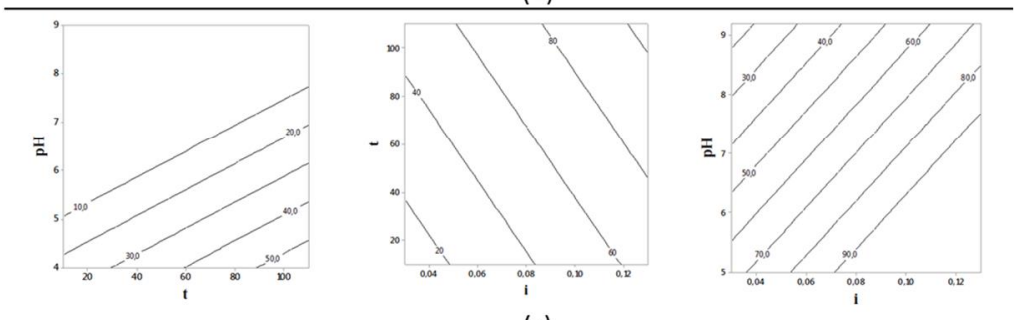

(c)

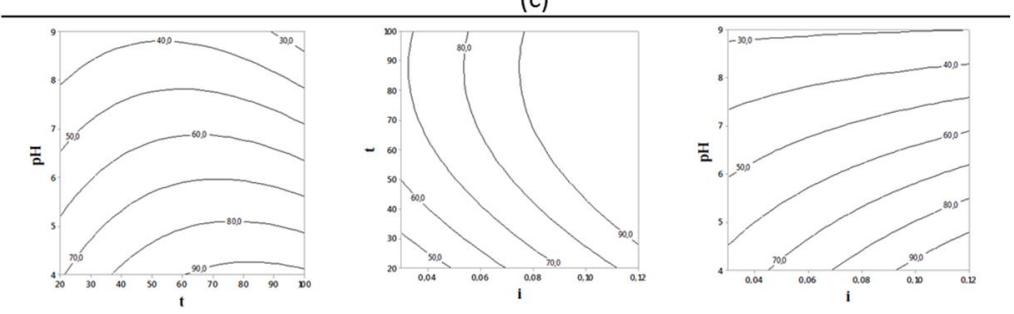

Figure 3. Estimates of percent color removal due to the combinations $\mathrm{i}$ and $\mathrm{pH}$, of $\mathrm{i}$ and $\mathrm{t}$ and $\mathrm{t}$ and $\mathrm{pH}$, given the best value of the third controllable parameter of interest of the turbidity samples: (a) low; (b) medium; (c) high. 
Table 5. Coded and uncoded statistical models for COD percentage removal of the samples.

\begin{tabular}{|c|c|c|c|c|}
\hline Sample & & Regression equation & $\mathbf{R}^{2}$ & $\mathbf{L F}$ \\
\hline \multirow{3}{*}{$\begin{array}{l}\text { Low water } \\
\text { turbidity }\end{array}$} & Cod & $\mathrm{COD}=81.6-14.29 * \mathrm{t}-5.70 * \mathrm{i}+1.13 * \mathrm{pH}-19.40 * \mathrm{t}^{2}-18.39 * \mathrm{i}^{2}-28.05 * \mathrm{pH}^{2}$ & \multirow{3}{*}{0.79} & \multirow{3}{*}{0.958} \\
\hline & Uncod & $\mathrm{COD}=-647+2.111 * \mathrm{t}+4185 * \mathrm{i}+162.8 * \mathrm{pH}-0.02156 * \mathrm{t}^{2}-29420 * \mathrm{i}^{2}-12.47 * \mathrm{pH}$ & & \\
\hline & $\mathrm{BP}$ & $\mathrm{t}=49 ; \mathrm{i}=0.071 ; \mathrm{pH}=6.5$ & & \\
\hline \multirow{3}{*}{$\begin{array}{l}\text { Medium water } \\
\text { turbidity }\end{array}$} & Cod & $\mathrm{COD}=96.7-3.73 * \mathrm{t}+17.78 * \mathrm{i}-8.9 * \mathrm{pH}-28.04 * \mathrm{t}^{2}-22.47 * \mathrm{i}^{2}-18.57 * \mathrm{pH} \mathrm{H}^{2}$ & \multirow{3}{*}{0.85} & \multirow{3}{*}{0.297} \\
\hline & Uncod & $\mathrm{COD}=-574-3.61 * \mathrm{t}+6104 * \mathrm{i}+101.3 * \mathrm{pH}-0.03115 * \mathrm{t}^{2}-35951 * \mathrm{i}^{2}-8.25 * \mathrm{pH}^{2}$ & & \\
\hline & BP & $\mathrm{t}=58 ; \mathrm{i}=0.085 ; \mathrm{pH}=6.1$ & & \\
\hline \multirow{3}{*}{$\begin{array}{l}\text { High water } \\
\text { turbidity }\end{array}$} & Cod & $\mathrm{COD}=79.14-4.01 * \mathrm{pH}+7.43 * \mathrm{i}-7.27 * \mathrm{pH}^{2}-6.57 * \mathrm{i}^{2}+11.37 * \mathrm{pH} * \mathrm{i}$ & \multirow{3}{*}{0.74} & \multirow{3}{*}{0.769} \\
\hline & Uncod & $\mathrm{COD}=47.7-0.13 * \mathrm{pH}+692 * \mathrm{i}-1.163 * \mathrm{pH}^{2}-10515 * \mathrm{i}^{2}+181.9 * \mathrm{pH}^{*} \mathrm{i}$ & & \\
\hline & $\mathrm{BP}$ & $\mathrm{i}=0.1 ; \mathrm{pH}=7.7$ & & \\
\hline
\end{tabular}

Cod: model with coded coefficients; Uncod: model with uncoded coefficients; BP: best point; $\mathrm{R}^{2}$ : coefficient of determination; $\mathrm{LF}$ : lack of fit.

(a)

.

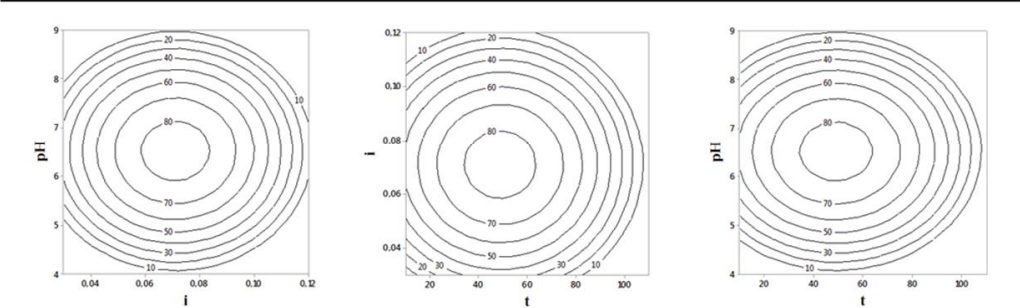

(c)

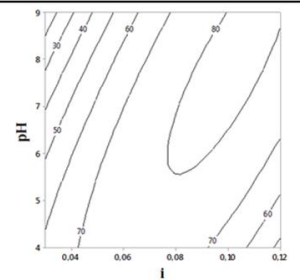

Figure 4. Estimates of COD percent removal due to the combinations $\mathrm{i}$ and $\mathrm{pH}$, of $\mathrm{t}$ and $\mathrm{i}$ and $\mathrm{t}$ and $\mathrm{pH}$, given the best value of the third controllable parameter of interest of the turbidity samples: (a) low; (b) medium; (c) high. 
Table 6. Coded and uncoded statistical models for turbidity percentage removal of the samples.

\begin{tabular}{|c|c|c|c|c|}
\hline Sample & & Regression equation & $\mathbf{R}^{2}$ & $\mathbf{L F}$ \\
\hline \multirow{3}{*}{$\begin{array}{l}\text { Low water } \\
\text { turbidity }\end{array}$} & Cod & $\mathrm{T}=24.51+0.86 * \mathrm{i}-20.23 * \mathrm{pH}-6.2 * \mathrm{i}^{2}-6.61 * \mathrm{pH}^{2}$ & \multirow{3}{*}{0.90} & \multirow{3}{*}{0.054} \\
\hline & Uncod & $\mathrm{T}=-70.3+1524 * \mathrm{i}+24.7 * \mathrm{pH}-9932 * \mathrm{i}^{2}-2.94 * \mathrm{pH}^{2}$ & & \\
\hline & $\mathrm{BP}$ & $\mathrm{i}=0.076 ; \mathrm{pH}=4.2$ & & \\
\hline \multirow{3}{*}{$\begin{array}{l}\text { Medium water } \\
\text { turbidity }\end{array}$} & Cod & $\mathrm{T}=75.24+6.03 * \mathrm{i}-8.05 * \mathrm{pH}$ & \multirow{3}{*}{0.57} & \multirow{3}{*}{0.315} \\
\hline & Uncod & $\mathrm{T}=92.0+241.2 * \mathrm{i}-5.37 * \mathrm{pH}$ & & \\
\hline & $\mathrm{BP}$ & $\mathrm{i}=0.13 ; \mathrm{pH}=4$ & & \\
\hline \multirow{3}{*}{$\begin{array}{l}\text { High water } \\
\text { turbidity }\end{array}$} & Cod & $\mathrm{T}=85.08-13.166 * \mathrm{pH}+2.717 * \mathrm{i}+0.084 * \mathrm{t}-3.576 * \mathrm{pH}^{2}-4.62 * \mathrm{t}^{2}-2.830 * \mathrm{pH}^{*} \mathrm{t}$ & \multirow{3}{*}{0.97} & \multirow{3}{*}{0.343} \\
\hline & Uncod & $\mathrm{T}=53.62+4.43 * \mathrm{pH}+108.7 * \mathrm{i}+0.864 * \mathrm{t}-0.572 * \mathrm{pH}^{2}-0.00514 * \mathrm{t}^{2}-0.0377 * \mathrm{pH} * \mathrm{t}$ & & \\
\hline & $\mathrm{BP}$ & $\mathrm{t}=90 ; \mathrm{i}=0.1 ; \mathrm{pH}=2.5$ & & \\
\hline
\end{tabular}

Cod: model with coded coefficients; Uncod: model with uncoded coefficients; BP: best point; $\mathrm{R}^{2}$ : coefficient of determination; $\mathrm{LF}$ : lack of fit.

(a)

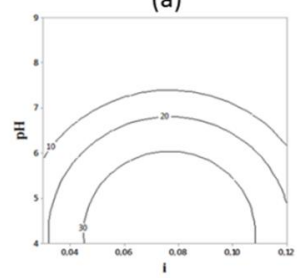

(c)
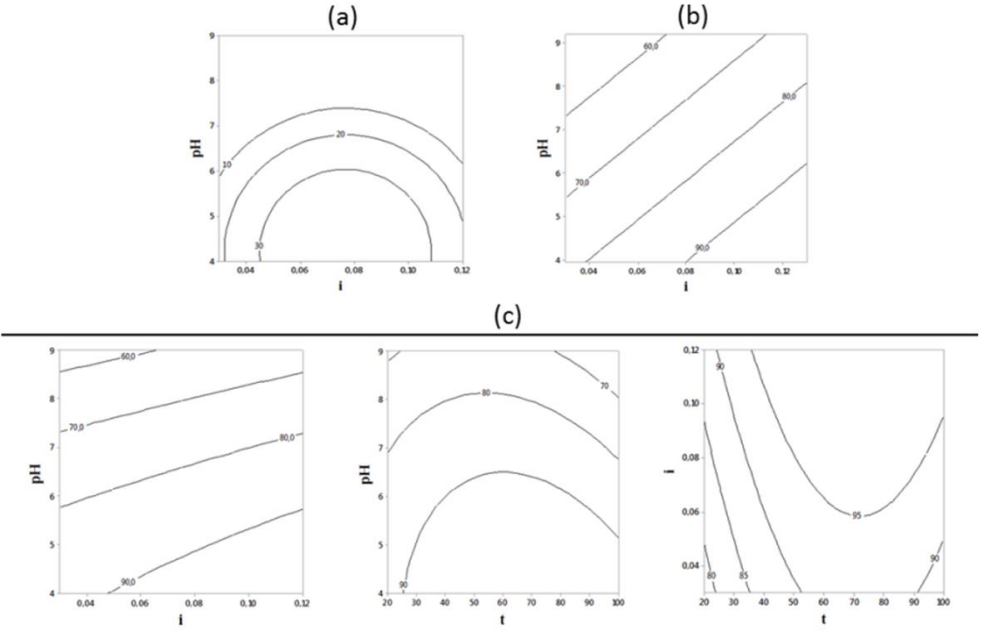

Figure 5. Estimates of turbidity percent removal due to the combinations i and $\mathrm{pH}$, of $t$ and $i$ and $t$ and $\mathrm{pH}$, given the best value of the third controllable parameter

of interest of the turbidity samples: (a) low; (b) medium; (c) high.

\subsection{Chemical oxygen demand removal}

The negative quadratic terms of the three types of water indicated the possibility to maximize the response $(\mathrm{p}<0.05)$. Partially deriving the models of table 5 in relation to each of the input variables and equaling zero, the optimal values are: $\mathrm{pH}=6.5, \mathrm{i}=0.07 \mathrm{~A}$ and $\mathrm{t}=49 \mathrm{~s}$, for low turbidity water; $\mathrm{pH}=6.1, \mathrm{i}=0.085 \mathrm{~A}$ and $\mathrm{t}=58 \mathrm{~s}$, for medium turbidity water; and $\mathrm{pH}=7.7$ and $\mathrm{i}=0.1 \mathrm{~A}$, for water with high turbidity. The isolines of the contour graphs representing the model for water with high turbidity are elliptic. Due to the effect of the iteration $\mathrm{pH} \times \mathrm{i}$ with positive signal that denotes synergy between the parameters, which leads to an increase in the response in the region with simultaneous increase of these input variables in the model for the more turbid water. The electrolysis time was non-significant in the studied range, so the parameter can be fixed at the value that represents greater economy and operational ease, as can be seen in Figure 4.

\subsection{Turbidity removal}

The percentage removal of turbidity for water with low turbidity increases $(p<0.05)$ due to the increase in i up to $0.076 \mathrm{~A}$ and decrease of $\mathrm{pH}$ up to 4.2 , which provides the maximum removal. For water with medium turbidity, the turbidity removal increases $(p<0.05)$ with the linear decreasing of $i$ and $\mathrm{pH}$, respectively. In the two previous models, 
electrolysis time was non-significant in the studied range, so it can be fixed at the value that represents greater economy and operational ease. The removal to water with high turbidity increases $(p<0.05)$ due to the linear increase of $i$, according to figure 5 , as well as the increase of $t$ up to $90 \mathrm{~s}$ and the decrease of $\mathrm{pH}$ up to 2.5. The models estimated for water with medium and high turbidity, according figure 6 , indicated not possibility of reaching the maximization of the turbidity removal, so that better results of the response variable would be obtained if there were displacement of the non-optimized parameters.

\subsection{Desirability}

The models for the three water types, seen in table 6 , were found and then the desirability function used to maximize the response variables simultaneously. In general, satisfactory values of desirability ( $\mathrm{D}>0.7$ ) were found when the lower limit of permissible percentage removal was zero, indicating that there is a correlation between apparent color, COD and water turbidity. However, the desirability values were lower when the permissible lower limit is the local standard, according table. For water with high initial turbidity, a desirability value that met the constraints imposed by the local standard was not found, since the initial values of color, COD and input turbidity were high and consequently required larger removals than those for the samples with low and medium initial turbidity.

Table 7. Desirable values for the types of water, and values of input and output variables considering desirability when the lower limit of permissible percentage removal is zero.

\begin{tabular}{ccccccccc}
\hline & $\mathbf{D}^{(\mathbf{1})}$ & $\mathbf{D}^{(\mathbf{2})}$ & $\mathbf{p H}$ & $\begin{array}{c}\mathbf{t} \\
(\mathbf{s})\end{array}$ & $\begin{array}{c}\mathbf{i} \\
(\mathbf{A})\end{array}$ & $\begin{array}{c}\mathbf{C} \\
\left(\boldsymbol{\mu} \mathbf{S ~ \mathbf { ~ m } ^ { - 1 } )}\right.\end{array}$ & $\begin{array}{c}\mathbf{C O D} \\
\left(\mathbf{m g ~ L}^{-1} \mathbf{O}_{2}\right)\end{array}$ & \\
\hline $\begin{array}{c}\text { Low } \\
\text { Water } \\
\text { Turbidity }\end{array}$ & 0.76 & 0.63 & 4.8 & 60 & 0.08 & 30 & 43 & 39 \\
\hline $\begin{array}{c}\text { Medium Water } \\
\text { Turbidity }\end{array}$ & 0.86 & 0.72 & 5 & 64 & 0.1 & 85 & 87 & 88 \\
\hline $\begin{array}{c}\text { High } \\
\text { Water } \\
\text { Turbidity }\end{array}$ & 0.9 & 0.24 & 2.6 & 84 & 0.07 & 96 & 68 & 97 \\
\hline
\end{tabular}

(1) Desirability when the lower limit of permissible percentage removal is zero.

(2) Desirability when the permissible lower limit is the local standard.

${ }^{(3)}$ Percentage of turbidity removal.

Table 7 shows that for the three types of water, initial acid conditions favor the increased efficiency of removal of the evaluated aesthetic/organoleptic parameters. The initial $\mathrm{pH}$ is a significant factor as reported frequently in the literature (Ulu et al., 2015; Feride et al., 2014; Hussin et al., 2017; Hu et al., 2017; Hashin et al., 2017). The formation, stability and solubility of the metal hydroxides depend on water $\mathrm{pH}$ during the electrocoagulation process; at low $\mathrm{pH}(\mathrm{pH}<5)$, the mechanism of charge neutralization prevails due to the formation of cationic metal species resulting from the reaction of aluminum with water; $\mathrm{pH}$ values between 5 and 7 promote the formation of the precipitated hydroxide of the metal favoring the coagulation by sweeping (Kourdali et al., 2013).
For all samples, the optimal electrolysis time (50-110 s) is within the stage of the reactive state reported by previous research (Dubrawski et al., 2013; Ulu et al., 2014). These studies evaluated long times compared with those evaluated by this study. However, the exponential increase in removal observed by these authors at the beginning of treatment is similar to the results found and arranged in table 7.

The time-intensity binomial of the current, plays an important role in the type of sample, since in addition to affecting the dissolution efficiency of aluminum. The magnitude of this product influences the increase of the coagulation $\mathrm{pH}$ given by the water hydrolysis in the reactor cathode and this process directly affects the efficiency of percentage 
removal of the studied pollutants. The results show that the product requirement for time and current intensity becomes higher as the initial turbidity conditions increase (when the $\mathrm{pH}$ value is 5), a higher dose of coagulant is required in the raw water conditions. Electrocoagulation offers as an advantage the operational flexibility in face of changes in the studied climatic conditions, since the dose of coagulant in water can be easily controlled by varying the time-intensity binominal of the current.

The perceived removal efficiencies are lower than those reported by Ulu et al. (2015). However, there is no need to displace the three input factors because it was possible to comply with the aesthetic/organoleptic standard stipulated for this process step $\left(\mathrm{COD}<18 \mathrm{mg} \mathrm{L}^{-1}\right.$, color $<15 \mathrm{uC}$ and turbidity $<5 \mathrm{NTU}$ ) considering the initial characterization of the study samples, as provided in table 3 .

\section{CONCLUSIONS}

An electrocoagulation reactor equipped with aluminum electrodes to treat three samples from the same water body collected at different times of the year was developed. Mathematical models established, allowed to find the best operation points for the percentage removal of apparent color, COD and turbidity. Maximizing COD removal from the three water types was possible. In general, satisfactory values of desirability $(\mathrm{D}>0.7$ ) were found, when the lower limit of permissible percentage removal of the three response variables was zero.

Due to the minimum required removals suggested by the local organoleptic standard (color < $15 \mathrm{uC}$ and turbidity $<5 \mathrm{NTU}$ ) and for the COD value indicated by WTS-UFV $\quad\left(<18 \mathrm{mg} \mathrm{L}^{-1} \mathrm{O}_{2}\right)$, it is not necessary to displace the three parameters of the studied input. The simulation results for the three water types showed that the product requirement for time and current intensity becomes greater as the initial turbidity conditions increase when the initial $\mathrm{pH}$ of the samples is set at a specific value; with increasing $\mathrm{t} \times \mathrm{i}$ product, there will be increase of the coagulant dose in the raw water. As an advantage, the electrocoagulation offers the operational flexibility against the climatic conditions change of the surface water bodies, since, the concentration of coagulant of the water can be easily controlled varying the studied operational parameters.

\section{Acknowledgments}

The authors acknowledge the financial support of the Conselho Nacional de Desenvolvimento Científico e Tecnológico (CNPq), Coordenação de Aperfeiçoamento de Pessoal de Nível Superior (CAPES) and Fundação de Amparo à Pesquisa do Estado de Minas Gerais (FAPEMIG) and the staff of WTS-UFV for the provision of information and support.

\section{R E F E R E N C E S}

ABNT. NBR 12216, Manuais, Projetos, Pesquisas de Engenharia Ambiental. Rio de Janeiro, 1989. Available at: <https://www.docsity.com/pt/nbr12216/4720588/>. Accessed on March 3rd, 2020.

AMIRTHARAJAH, A.; MILLS, K. M. Rapid mix design for mechanisms of alum coagulation. Am. Water Work. Assoc., v. 74 , n. 4, p. 210-2016, 1982.

APHA (American Public Health Association), Standard Methods for the Examination of Water and Wastewater, 21st edition, Washington, D.C, 2016.

BASTOS, R. K. X.; OLIVEIRA, D. C.; FREITAS, A. G.; NASCIMENTO, L. E. Ensaios de tratabilidade e avaliação de desempenho. recursos fundamentais de projeto e operação de etas com vistas à otimização do tratamento e da qualidade da água. Available at: <http://servicos.semasa.sp.gov.br/admin/biblioteca/ docs/PDF/35Assemae016.pdf >. Accessed on March 3rd, 2020.

CHEN, G. Electrochemical technologies in wastewater treatment. Sep. Purif. Technol. v. 38, n.1, p. 11-41, 2004.

DI BERNADO, L; DI BERNADO, A.; CENTURIONE FILHO, P. L. Ensaios de tratabilidade de água e de resíduos gerados em estações de tratamento de água; Rima: São Carlos, 2002.

DUAN, J.; GREGORY, J. Coagulation by hydrolysing metal salts.. Adv. Colloid Interface Sci., v. , n. 475, p. $100 і ̈$ 102, 2003.

DUBRAWSKI, K. L.; FAUVEL, M.; MOHSENI, M. Metal type and natural organic matter source for 
direct filtration electrocoagulation of drinking water. J. Hazard. Mater., v. 244, p. 135-141, 2013.

ESCOBAR, C.; SOTO-SALAZAR, C.; TORAL, M. I. Optimization of the electrocoagulation process for the removal of copper, lead and cadmium in natural waters and simulated wastewater. J. Environ. Manage., v. 81 , n. 4, p. 384-391, 2006.

FERIDE, U. L. U.; BARISÇI, S.; KOBYA, M.; SÄRKKÄ, H.; SILLANPÄÄ, M. Batch Electrocoagulation Reactor for Natural Organic Matter Removal from Synthetic and Real Water Samples. J. Selçuk U. Nat. Appl. Sci., v. 1, p. 369-379, 2014.

GHERNAOUT, D.; IRKI, S.; BOUCHERIT, A. Removal of $\mathrm{Cu}^{2+}$ and $\mathrm{Cd}^{2+}$, and humic acid and phenol by electrocoagulation using iron electrodes. Desalin. Water Treat., v. 52, p. 3256-3270, 2014.

HASHIM, K. S.; SHAW, A.; AL KHADDAR, R.; PEDROLA, M. O.; PHIPPS, D. Iron removal, energy consumption and operating cost of electrocoagulation of drinking water using a new flow column reactor. J. Environ. Manage., v. 189, p. 98-108, 2017.

HOLT, P. K.; BARTON, G. W.; MITCHELL, C. A. The future for electrocoagulation as a localized water treatment technology. Chemosphere, v. 59, n. 3, p. 355-367, 2005.

HU, C.; SUN, J.; WANG, S.; LIU, R.; LIU, H.; QU, J. Enhanced efficiency in HA removal by electrocoagulation through optimizing flocs properties: Role of current density and $\mathrm{pH}$. Sep. Purif. Technol., v. 175, p. 248-254, 2017.

HUSSIN, F.; ABNISA, F.; ISSABAYEVA, G.; AROUA, M. K. Removal of lead by solarphotovoltaic electrocoagulation using novel perforated zinc electrode. J. Clean. Prod., v. 147, p. 206-216, 2017.

ISLAM, M. A.; SAKKAS, V.; ALBANIS, T. A. Application of statistical design of experiment with desirability function for the removal of organophosphorus pesticide from aqueous solution by low-cost material. J. Hazard. Mater., v. 170, p. 230-238, 2009.

JADHAV, S. V; BRINGAS, E.; YADAV, G. D.; RATHOD, V. K.; ORTIZ, I.; MARATHE, K. V. Arsenic and fluoride contaminated groundwaters: a review of current technologies for contaminants removal. J. Environ. Manage., v. 162, p. 306-325, 2015.
JIMENÉZ， C.; SÁEZ， C.; CAÑIZARES， P.; RODRIGO, M. A. Optimization of a combined electrocoagulation-electroflotation reactor. Environ. Sci. Pollut. Res., v. 23, n. 10, p. 9700-9711, 2016.

KOBYA, M.; DEMIRBAS, E.; GEBOLOGLU, U.; ONCEL, M. S.; YILDIRIM, Y. Optimization of arsenic removal from drinking water by electrocoagulation batch process using response surface methodology.. Desalin. Water Treat., v.51, n. 34, p.6676-6687, 2013.

KOBYA, M.; OZYONAR, F.; DEMIRBAS, E.; SIK, E.; ONCEL, M. S. Arsenic removal from groundwater of Sivas-k̦arkikla Plain, Turkey by electrocoagulation process: Comparing with iron plate and ball electrodes. J. Environ. Chem. Eng., v. 3, n. 2, p. 1096-1106, 2015.

KOURDALI, S.; BADIS, A.; SAIBA, A.; BOUCHERIT, A.; BOUTOUMI, H. Humic acid removal by electrocoagulation using aluminium sacrificial anode under influencing operational parameters. Desalin. Water Treat., v.52, n. 28, p. 5442-5453, 2013.

LU, F.; BARIk̦ÇI, S.; KOBYA, M.; SILLANPÄ̈̈, M. An evaluation on different origins of natural organic matters using various anodes by electrocoagulation. Chemosphere, v.125, p. 108114, 2015.

MENDOZA, M; SANTOS, R CELIA; SILVA, G; MUDADU, C. Validação do processo de eletrocoagulação e avaliação da eletrodissolução de eletrodos no tratamento de efluentes de abatedouros de aves. Quim.Nova, v. 40, n. 4, p. 447-453, 2017.

Minitab Inc. Statistical Software Data Analysis. Software. 2004.

MOUEDHEN, G.; FEKI, M.; WERY, M. D. P.; AYEDI, H. F. Behavior of aluminum electrodes in electrocoagulation process. J. Hazard. Mater., v. 150, n. 1, p. 124-135, 2008.

MOUSSA, D. T.; EL-NAAS, M. H.; NASSER, M.; AL-MARRI, M. J. A comprehensive review of electrocoagulation for water treatment: Potentials and challenges. J. Environ. Manage., v.186, n. 1, p. 24-41, 2017. 
PINTO, V. G.; HELlER, L.; BASTOS, R. K. X. Drinking water standards in South American countries: convergences and divergences. J. Water Health, v. 10, n. 2, p. 295-310, 2012.

ULU, F.; BARIKÇI, S.; KOBYA, M.; SÄRKKÄ, H.; SILLANPÄÄ, M. Removal of humic substances by electrocoagulation (EC) process and characterization of floc size growth mechanism under optimum conditions. Sep. Purif. Technol., v. 133, n. 8, p. 246-253, 2014.

UNICEF (United Nations Childrenôs Fund) and WHO (World Health Organization). Progress on household drinking water, sanitation and hygiene 2000-2017. Special focus on inequalities. New York:, 2019. Available at: <https://washdata.org/report/jmp-2019-washhouseholds>. Acessed on March 3rd, 2020.
VALENTE, G. F. S.; MENDONÇA, R. C. S.; PEREIRA, J. A. M.; FELIX, L. B. Artificial neural network prediction of chemical oxygen demand in dairy industry effluent treated by electrocoagulation. Sep. Purif. Technol., v. , n. 132, p. 627-xxx, 2014.

VOJNOVIC, D.; MONEGHINI, M.; RUBESSA, F.; ZANCHETTA, A. Simultaneaus Optimization of Several Response Variables in a Granulation Process. Drug Dev. Ind. Pharm., v. 19, n. 12, p. 1479-1496, 1993.

ZHU, B.; CLIFFORD, D. A.; CHELLAM, S. Comparison of electrocoagulation and chemical coagulation pretreatment for enhanced virus removal using microfiltration membranes. Water Res., v. 39, n. 13, p. 3098-3108, 2005. 